\title{
On the Chemical Constituents of Rice-embryo.
}

\author{
By
}

\author{
Riang-Ha KIMM and (the late) Taro Noguchr.
}

(Received March 1, 1933.)

Rice-embryo constitutes only $3 \%$ by weight of the whole grain and it is very difficult to separate from it in a pure state in large quantities, so its chemical composition has not yet been studied thoroughly.

In 1912, Luigi Bernardini(1) reported on the analysis of the ash and the distribution of phosphoric acid in different forms in the embryo and he pointed out that the embryo is very rich in phosphoric acid of which the greater part is in the phytin-form.

M. Hamada ${ }^{(2)}$ isolated protein from the embryo, determined the distribution of amino acids in its hydrolytic products and demonstrated by feeding experiment that the protein in the embryo has a very high nutritive value. Later, Hirai ${ }^{(3)}$ investigated the ethersoluble substances of the embryo and isolated palmitic, oleic and linolic acids as the chief constituents of fats. Further, from the unsaponifiable fraction, he obtained the so-called Burian's phytosterol, besides a mixture of sterols which was readily soluble in organic solvents. From its high melting point $\left(144^{\circ} \mathrm{C}\right)$ and low rotatory power $\left(-23^{\circ}\right)$ it was assumed by hin to contain a dihydrositosterol.

Quite recently, the rice-polishing factories, Munechika and Niko \& Co. have independently invented new polishing machines by which the embryo can be easily separated from the grain in an intact state and large quantities of these samples were kindly supplied by these factories to the present authors for investigation.

These samples, when carefully refined, looked quite homogeneous and were absolutely free from crushed grains, brans or other impurities. They contained in average $24 \%$ fatty matter, including about $1.2 \%$ unsaponifiable substances, besides a little waxes and a phytosterine-glucoside (phytosterolin). The waxes chiefly consisted of melissyl cerotate. Of the fatty acids, 25\% were saturated and $75 \%$ unsaturated acids. From the saturated acids, palmitic, arachidic, and cerotic acids were isolated and identified; further, the presence of a little myristic and stearic acids were proved. The unsaturated acids consisted almost exclusively of oleic and linolic acids. The absence of other higher unsaturated acids was confirmed by the examination of the bromination products.

The unsaponifiable matter was treated with aceton and absolute alcohol and separated into two parts, i. e. a white amorphous powder $(80 \%)$ and a 
brown viscous syrup (20\%). The former gave strong Liebermann reaction for sterine and the characteristic reaction for ergosterine. By repeated recrystallization from various organic solvents, some melissyl alcohol, a small amount of dihydrositosterine, stigmasterine and the so-called Anderson's $\gamma$-sitosterine ${ }^{(4)}$ were isolated and identified. The existence of a little ergosterine was confirmed by converting it into vitamin $\mathrm{D}$ by irradiation with ultraviolet rays. Futher, the mother liquor of the above substances was fractionally crystallized from hexane and a new sitosterine (m. p. $156^{\circ} \mathrm{C},[\alpha]_{\mathrm{D}}=-14.49^{\circ}$ ) was isolated. It was converted into an acetate (m. p. $111^{\circ} \mathrm{C},[\alpha]_{\mathrm{D}}=-9.68^{\circ}$ ) and a benzoate (m. p. $129^{\circ} \mathrm{C},[\alpha]_{\mathrm{D}}=+14.48^{\circ}$ ). This new sterine is comparatively soluble in light petroleum ether and more readily in hexane and other organic solvents. The so-called Anderson's $a$-sitosterine ${ }^{(4)}$, which was presumed by him to exist in rice polishing oil, is most probably the mixture of various sterines.

A cerebroside-like substance was also detected in the ether extract of the embryo. Probably it is the same as that obtained by W. Trier ${ }^{(5)}$ from rice grain. The nature of this substance will be investigated later on.

The authors have thus confirmed that the composition of the embryo oil closely resembles that of the polishing oil,

\section{Experimental.}

(I) General composition of rice-embryo.

The composition of the purified embryo, supplied from tne Niko \& Co., is compared with that reported by each of Sawamura and Hamada in the following table :

\begin{tabular}{l|c|c|c}
\hline \hline & Present authors & Sawamura & Hamada \\
\hline Moisture & 9.83 & 5.73 & 10.41 \\
Crude protein & 21.26 & 24.30 & 20.76 \\
Protein & 18.10 & - & 17.56 \\
Crude fat & 23.87 & 21.05 & 20.66 \\
Fibre & 3.48 & 9.77 & 10.11 \\
N-free extract & 33.76 & 25.68 & 27.82 \\
Ash & 9.09 & 13.47 & 10.24 \\
Pentosan & $5 .-$ & - & - \\
Carbohydrate & $21 .-$ & $1.3 .-$ & - \\
\hline
\end{tabular}

The composition of the ash is compared with that of Bernardini(1) as follows: 


\begin{tabular}{l|c|c||c|c|c}
\hline & $\begin{array}{c}\text { Present } \\
\text { authors }\end{array}$ & Bernardini & & $\begin{array}{c}\text { Present } \\
\text { authors }\end{array}$ & Bernardini \\
\hline $\mathrm{P}_{2} \mathrm{O}_{5}$ & 5.020 & 6.200 & $\mathrm{MgO}$ & 1.104 & 1.389 \\
$\mathrm{SiO}_{2}$ & 0.370 & 0.250 & $\mathrm{Mn}_{3} \mathrm{O}_{4}$ & 0.012 & trace \\
$\mathrm{Fe}_{2} \mathrm{O}_{3}$ & 0.064 & 0.060 & $\mathrm{~K}_{2} \mathrm{O}$ & 2.022 & 1.691 \\
$\mathrm{CaO}$ & 0.312 & 0.279 & $\mathrm{Na}_{2} \mathrm{O}$ & 0.196 & trace \\
\hline
\end{tabular}

Bernardini moreover determined the distribution of phosphoric acid in the embryo and in the whole grain, with the following results:

\begin{tabular}{|c|c|c|c|c|}
\hline \multirow{2}{*}{$\mathrm{P}_{2} \mathrm{O}_{5}$ in form of } & \multicolumn{2}{|c|}{ Embryo } & \multicolumn{2}{|c|}{ Seed } \\
\hline & $\begin{array}{l}\text { In } 100 \text { parts of } \\
\text { dry matter }\end{array}$ & $\begin{array}{l}\text { In } 100 \text { parts of } \\
\text { total } \mathrm{P}_{2} \mathrm{O}_{5}\end{array}$ & $\begin{array}{l}\text { In } 100 \text { parts of } \\
\text { dry mattex }\end{array}$ & $\begin{array}{c}\text { In } 100 \text { parts of } \\
\text { total } \mathrm{F}_{2} \mathrm{O}_{5}\end{array}$ \\
\hline Lecithin & 0.04 & 0.64 & 0.003 & 0.35 \\
\hline Phosphatides & 0.22 & 3.54 & 0.018 & 1.86 \\
\hline Phytin & 5.14 & 82.90 & 0.436 & 45.68 \\
\hline Inōrganic salts & 0.04 & 0.64 & trace & $\longrightarrow$ \\
\hline Nucleic acids & 0.76 & 12.28 & 0.502 & 52.61 \\
\hline Total & 6.20 & 100.00 & 0.950 & 100.00 \\
\hline
\end{tabular}

The above table shows that the embryo is very rich in phospooric acid of which the greater part is in the phytin-form.

(II) Chemical properties of the embryo oil:

The chemical constants of the embryo oil, extracter from the above sample with ether, are compared with the result obtained by Hirai ${ }^{(3)}$ and with that of polishing oil, reported by Takahashi ${ }^{(6)}$ :

\begin{tabular}{l|c|c|c}
\hline & \multicolumn{2}{|c|}{ Embryo oil } & Polishing ôil \\
\cline { 2 - 4 } & Present authors & Hirai & Takahashi \\
\hline Acid value & 26.5 & 29.74 & 14.36 \\
Saponification value & 183.0 & 212.19 & 183.54 \\
Acetyl value & 10.6 & - & - \\
Iodine value & 114.8 & 106.63 & 104.73 \\
Hehner value & 93.2 & 95.16 & 95.95 \\
Reichert-Wollny value & 0.4 & 2.05 & 0.73 \\
Unsaponifiable matter & $5.28 \%$ & $4.00 \%$ & $3.40 \%$ \\
\hline
\end{tabular}

The fatty acids obtained by saponifying the embryo oil with alcoholic potash in the usual way had the following constants: 


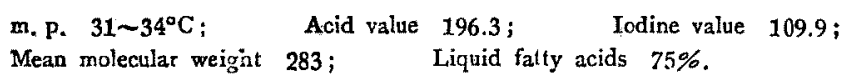

\section{(III) Phytosterolin (pliytosterine-glucoside).}

When the etherial extract of the rice-embryo was left standing for several hours, a brown precipitate separated out, which when recrystallized from amyl alcohol formed white needles melting at $283 \sim 290^{\circ} \mathrm{C}$ and gave the Liebermann's sterine reaction as well as the Molisch's reaction for sugar. From the analysis as well as from other properties, this substance was proved to be identical with the phytosterolin isolated from wheat-embryo by Nakamura and Ichiba ${ }^{(T)}$.

Analysis of the phytosterolin from rice-embryo:

$\begin{array}{cccccc} & \text { Substance }(\mathrm{mg}) & \mathrm{CO}_{2}(\mathrm{mg}) & \mathrm{H}_{2} \mathrm{O}(\mathrm{mg}) & \mathrm{C}(\%) & \mathrm{H}(\%) \\ \text { I } & 3.752 & 10.005 & 3.464 & 72.73 & 10.33 \\ \text { II } & 3.711 & 9.847 & 3.415 & 72.37 & 10.29 \\ & \text { Calculated for phytosterolin }\left(\mathrm{C}_{33} \mathrm{H}_{55} \mathrm{O}_{6}\right), & 72.30 & 10.20\end{array}$

Like other sterines, this substance forms an acetate melting at $167 \sim 168^{\circ} \mathrm{C}$. Analysis of the acetate:

\begin{tabular}{ccccc} 
Substance (mg) & $\dot{\mathrm{CO}}_{2}(\mathrm{mg})$ & $\mathrm{H}_{3} \mathrm{O}(\mathrm{mg})$ & $\mathrm{C}(\%)$ & $\mathrm{H}(\%)$ \\
4.378 & 11.059 & 3.503 & 68.90 & 8.95 \\
& \multicolumn{2}{c}{ Calculated for $\mathrm{C}_{\mathbf{1}_{4}} \mathrm{H}_{84} \mathrm{O}_{10}$} & 68.67 & 6.94
\end{tabular}

It forms also a benzoate melting at $198^{\circ} \mathrm{C}$.

Analysis of the benzoate:

$\begin{array}{ccccc}\text { Substance }(\mathrm{mg}) & \mathrm{CO}_{2}(\mathrm{mg}) & \mathrm{H}_{2} \mathrm{O}(\mathrm{mg}) & \mathrm{C}(\%) & \mathrm{H}(\%) \\ 3.131 & 8.726 & 2.169 & 76.01 & 7.75 \\ & \text { Calculated for } \mathrm{C}_{04} \mathrm{H}_{i_{2}} \mathrm{O}_{10} & 75.90 & 7.52\end{array}$

(IV) Separation of saturated fatty acids.

Rice-embryo $(1.5 \mathrm{~kg})$ was boiled with 3.5 litres of $90 \%$ alcohol for three hours, filtered while hot and the residue was extracted three times each with 2.5 litres of $90 \%$ alcohol. The combined extract was allowed to stand overnight, whereby a flocky precipitate separated out which chiefly consisted of waxes. It was filtered off and the filtrate was evaporated in vacuum and the residue was extracted with ether. The etherial extract was, after evaporating off the ether, saponified with alcoholic potash according to the usual method. From the mixed fatty acids thus obtained the solid saturated acids were separated by Tortelli Ruggeri's method. They had the following properties :

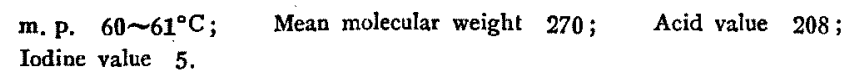

The solid acids were now mixed with sand and dried on a waterbath for ten days and extracted with ether. The etherial solution was evaporated, 
the residue was again dissolved in petroleum ether, filtered, and the filtrate was evaporated, whereby, $100 \mathrm{~g}$ saturated acids were obtained.

For the isolation of each fatty acid, the above acid mixture was converted into methyl ester and subjected to fractional distillation. For this purpose the mixture was dissolved in $220 \mathrm{cc}$ methyl alcohol, treated with dry $\mathrm{HCl}$ gas until the solution absorbed about $8 \mathrm{~g}$ of the acid and after heating for two hours on a water-bath the solution was shaken with ether. The etherial extract was, after washing with water to remove the methyl alcohol and hydrochloric acid, fractionally distilled under diminished pressure $(8 \mathrm{~mm})$. In this way the following fractions were obtained:

\begin{tabular}{l|c|c}
\hline Fraction & Temperature $\left({ }^{\circ} \mathrm{C}\right)$ & Yield $(\mathrm{g})$ \\
\hline I & $160 \sim 176$ & 1.5 \\
UI & $176 \sim 186$ & 80.5 \\
III & $186 \sim 213$ & 7.2 \\
IV (residue) & - & 15.5 \\
\hline
\end{tabular}

Each fraction was now saponified and free fatty acids thus regenerated had the following constants:

\begin{tabular}{c|c|c|c|c}
\hline & Yield $(\mathrm{g})$ & Acid value & Mean mol. wt. & m. p. $\left({ }^{\circ} \mathrm{C}\right)$ \\
\hline I & 1.2 & 220.6 & 254.2 & $53 \sim 54$ \\
II & 75.0 & 216.8 & 258.7 & $58 \sim 59$ \\
II & 6.5 & 212.8 & 263.6 & $59 \sim 60$ \\
IV & 12.3 & - & - & - \\
\hline
\end{tabular}

The fraction I was recrystallized from $90 \%$ alcohol and the residue from the mother liquor, after evaporating the alcohol, was recrystallized twice from $80 \%$ alcohol. Again, the residuals from the combined mother liquors were recyrstallized twice from $70 \%$ alcohol. Then, evaporating off the combined mother liquors, the residual was dissolved in hot $70 \%$ alcohol, decolorized with animal charcoal and allowed to stand overnight. Thereupon, a crystalline precipitate separated out which melted at $54^{\circ} \mathrm{C}$ and had the mean molecular weight 234. Most probably it was myristic acid containing some impurities.

The fraction II, when recrystallized four times from $95 \%$ alcohol, melted at $62 \sim 63^{\circ} \mathrm{C}$.and had the acid value 218.8 and the mean molecular weight 256.3. The analysis gave the following results:

\begin{tabular}{lrcccc} 
& Substance (mg) & $\mathrm{CO}_{2}(\mathrm{mg})$ & $\mathrm{H}_{2} \mathrm{O}(\mathrm{mg})$ & $\mathrm{C}(\%)$ & $\mathrm{H}(\%)$ \\
I & 4.315 & 11.900 & 4.853 & 75.22 & 12.58 \\
$\mathrm{II}$ & 4.001 & 11.000 & 4.487 & 74.98 & 12.55 \\
& \multicolumn{3}{c}{ Calculated for $\mathrm{C}_{16} \mathrm{H}_{32} \mathrm{O}_{2}$} & 74.92 & 12.59
\end{tabular}


The analysis shows that it was palmitic acid.

The fraction III was coloured slightly yellowish, so it was dissolved in alcohol and after being decolorized with animal charcoal, recrystallized fifteen times from absolute alcohol. The crystals thus obtained melted at $59 \sim 61^{\circ} \mathrm{C}$ and had the acid value 197.8 and the mean molecular weight 282 . It was proved to be a mixture of stearic and palmitic acids, but the yield was too small for further purification.

The fraction IV was dissolved in $500 \mathrm{cc}$ absolute alcohol and allowed to stand for 48 hours. The precipitate formed thereby was collected and washed with absolute alcohol: the yield, $3.4 \mathrm{~g}$. After recrystallization from absolute alcohol eight times more, the crystals obtained melted at 76.5 $77.5^{\circ} \mathrm{C}$ with the acid value 141.1 and the mean molecular weight 398.2 . The analysis gave the following results :

\begin{tabular}{|c|c|c|c|c|c|}
\hline & Substance (mg) & $\mathrm{CO}_{2}(\mathrm{mg})$ & $\mathrm{H}_{2} \mathrm{O}(\mathrm{mg})$ & $\mathrm{C}(\%)$ & $\mathrm{H}(\mathrm{g}$ \\
\hline I & 3.903 & 11.209 & 4.533 & 78.33 & 12.99 \\
\hline & 3.587 & 10.301 & 4.250 & 78.33 & 13.25 \\
\hline & \multicolumn{3}{|c|}{ Calculated for $\mathrm{C}_{26} \mathrm{H}_{52} \mathrm{O}_{2}$} & 78.61 & 13.1 \\
\hline
\end{tabular}

The analysis shows the agreement with cerotic acid. The filtrates of cerotic acid were united, evaporated and the residue $x$ as recrystallized three times from absolute alcohol. The fatty acid obtained in this way had the melting point $76^{\circ} \mathrm{C}$ and the mean molecular weight 318 . From this it was concluded that arachidic acid was present; but it could not be purified.

The mother liquor of fraction IV was diluted to $90 \%$ alcohol, the precipitate formed thereby was dissolved by heating and allowed to stand for three days, when the precipitate was collected, recrystallized from $90 \%$ alcohol and the filtrate therefrom was evaporated ancl the residue was recrystallized from $90 \%$ alcohol five times. The fatty acid thus obtained was long needles melting at $79.5 \sim 80^{\circ} \mathrm{C}$ with the acid value 164 and the mean molecular weight 342 .

Analysis of the fatty acid:

\begin{tabular}{|c|c|c|c|c|c|}
\hline & Substance (mg) & $\mathrm{CO}_{2}(\mathrm{mg})$ & $\mathrm{H}_{2} \mathrm{O}$ (mg) & $\mathrm{C}(\%)$ & II $(\%)$ \\
\hline I & 4.374 & 12.429 & 5.121 & 77.50 & 13.10 \\
\hline & 4.942 & 14.031 & 5.716 & 77.43 & 12.94 \\
\hline & \multicolumn{3}{|c|}{ Calculated for $\mathrm{C}_{22} \mathrm{H}_{44} \mathrm{O}_{2}$} & 77.57 & 13.03 \\
\hline
\end{tabular}

The analysis shows the substance to agree with behenic acid.

(V) Bromination of unsaturated fatty acids.

Unsaturated fatty acids $(150 \mathrm{~g})$ were brominated in usual way and the bromination products were digested with $2 \mathrm{~L}$ of boiling petroleum ether $(35 \sim$ $55^{\circ} \mathrm{C}$ ), whereby a clear solution was obtained leaving no insoluble residue. 
On standing overnight, $73 \mathrm{~g}$ of solid bromides separated out. The mother liquor, when concentrated to $1 / 3$ of its volume and allowed to stand for three weeks, gave $3 \mathrm{~g}$ more of solid bromides.

When the solid bromide thus obtained was recrystallized three times from $95 \%$ alcohol, it melted at $113^{\circ} \mathrm{C}$ and had the acid value 93.7 and the mean molecular weight 599.9 .

Analysis of the soild bromide :

$\begin{array}{cccc} & \text { Snlastance }(\mathrm{mg}) & \mathrm{AgBr}(\mathrm{mg}) & \mathrm{Br}(\%) \\ \text { I } & 6.645 & 8.295 & 53.12 \\ \text { II } & 6.030 & 7.553 & 53.30 \\ & \text { Calculated for } \mathrm{C}_{13} \mathrm{H}_{32} \mathrm{O}_{2} \mathrm{Br}_{4} & 53.33\end{array}$

The analysis shows it to agree with the tetrabromide of linolic acid.

When the filtrate of the solid bromide was evaporated, another bromide having $41.3 \%$ bromine was obtained. Probably it was the dibromide of oleic acid mixed with some tetrabromide.

(VI) Oxidation products of the unsaturated fatty acids.

When the unsaturated fatty acids were oxidized with alkaline premanganate according to the Hazura's method, $11.3 \mathrm{~g}$ insoluble hydroxyacids were obtained. They were treated with ether and separated into the ether-soluble and insoluble parts. The former, when recrystallized from absolute alcohol, melted at $131^{\circ} \mathrm{C}$ with the acid value 176.3 and the mean molecular weight 316.7. This was proved to be dihydroxystearic acid.

Analysis of the dihydoxystearic acid:

$\begin{array}{ccccc}\text { Substance }(\mathrm{g}) & \mathrm{CO}_{2}(\mathrm{~g}) & \mathrm{H}_{2} \mathrm{O}(\mathrm{g}) & \mathrm{C}(\mathrm{d}) & \mathrm{H}(\%) \\ 0.6982 & 0.2462 & 0.09852 & 68.35 & 11.14 \\ & \text { Calculated for } \mathrm{C}_{18} \mathrm{H}_{36} \mathrm{C}_{4} & 68.29 & 11.47\end{array}$

The ether-insoluble part, when recrystallized from absolute alcohol, melted at $173^{\circ} \mathrm{C}$, its acid value being 160.9 and the mean molecular weight, 394.1. It was sativic acid.

Analysis of the sativic acid:

\begin{tabular}{|c|c|c|c|c|c|}
\hline & Substance (mg) & $\mathrm{CO}_{2}(\mathrm{mg})$ & $\mathrm{H}_{2} \mathrm{O}$ (mg) & $\mathrm{C}(\%)$ & $\mathrm{H}(\%$ \\
\hline I & 3.352 & 7.620 & 3.036 & 62.00 & 10.13 \\
\hline 5 & 3.611 & 8.178 & 3.391 & 62.07 & 10.3 \\
\hline & \multicolumn{3}{|c|}{ Calculated for $\mathrm{C}_{18} \mathrm{I}_{30} \mathrm{O}_{6_{*}}$} & 62.07 & 10.3 \\
\hline
\end{tabular}

Linusic or isolinusic acid could not be detected.

(VII) Unsaponifiable matter.

When $20 \mathrm{~kg}$ rice.embryo was extracted with benzene, about $4 \mathrm{~kg}$ dark brown oil was obtained. It was dissolved in $12 \mathrm{I}$. ether, a little insoluble waxy substance was filtered off and evaporated. The oil thus obtained was saponified with alcoholic potash in the usual way and $150 \mathrm{~g}$ of an uusaponifiable 
substance were obtained. It was a light brown semi-solid mass having a characteristic odour and giving a strong Liebermann-Buchard's reaction as well as the colour reaction of ergosterine. By treating with acetone and absolute alcohol it was separated into two part, i. e. (A) a white amorphous solid (120 g) and (B) a brown syrup ( $30 \mathrm{~g}$ ).

(A) From the spectrographic studies it was calculated that the amorphous solid contained about $0.4 \sim 0.5 \%$ ergosterine. When irradiated with ultra-violet rays and tested on rats, the existence of vitamin $\mathrm{D}$ was clearly demonstrated.

(1) Melissyl alcohol.

When the amorphous solid (A), mentioned above, was recrystallized several times from absolute alcohol until it gave no more Liebermann-Buchard's reaction, about $0.05 \mathrm{~g}$ crystals was obtained which melted at $83^{\circ} \mathrm{C}$.

$\begin{array}{cccll}\text { Substance }(\mathrm{mg}) & \mathrm{CO}_{2}(\mathrm{mg}) & \mathrm{H}_{2} \mathrm{O}(\mathrm{mg}) & \mathrm{C}(\%) & \text { II }(\%) \\ 2.798 & 6.462 & 3.524 & 82.48 & 14.09 \\ & \text { Calculated for } \mathrm{C}_{30} \mathrm{H}_{62} \mathrm{O} & 82.19 & 14.15\end{array}$

The analysis shows it to agree with melissyl alcohol.

(2) Dihydrositosterol.

The mother liquors of the last few fraction of the said recrystallization were combined and evaporated. About $30 \mathrm{~g}$ of the residue thus obtained were again repeatedly recrystallized from absolute alcohol, and after drying, it weighed $3.2 \mathrm{~g} ; \mathrm{m} . \mathrm{p} .132^{\circ} \mathrm{C},[a]_{b}^{22}=-6.20^{\circ}$ The unsaturated sterines were decomposed by the Anderson's method, and about $0.13 \mathrm{~g}$ dihydrositosterine (m. p. $144^{\circ} \mathrm{C},[\alpha]_{\mathrm{D}}^{22}=+24.28^{\circ}$ ) was isolated and identifiedl.

The sterol obtained from the combined filtrate of the above recrystallization melted at $138 \sim 140^{\circ} \mathrm{C},[a]_{\mathrm{D}}^{\mathrm{a}}=-26^{\circ}$. This was extracted three times with a large quantity of petroleum ether $\left(50^{\circ} \mathrm{C}\right)$ and then it was converted into acetate ; m. p. $115 \sim 11^{\circ} \mathrm{C},[\alpha]_{\mathrm{b}}^{22}=-23.98^{\circ}$.

(3) Tetrabromide of stigmasterine acetate.

When the acetate, mentioned above, was recrystallized ten times from absolute alcohol, the top fraction $(12 \mathrm{~g})$ melted at $138^{\circ} \mathrm{C}$ and had the rotation, $[\alpha]_{D}^{19}=-43.7^{\circ}$. This fraction was brominated by the Windaus-Hauth method adding an excess of glacial acetic acid. The precipitate was collected on a filter, dissolved again in chloroform and thrown down by methyl alcohol ; m. p. $204 \sim 205^{\circ} \mathrm{C}$.

Analysis of the bromide:

$\begin{array}{cccc} & \text { Substance (mg) } & \mathrm{AgBr}(\mathrm{mg}) & \mathrm{Br}(\%) \\ \text { I } & \sim 5.235 & 4.970 & 40.40 \\ \text { II } & 8.330 & 8.030 & 41.00 \\ & \text { Calculated for } \mathrm{C}_{32} & \mathrm{H}_{52} \mathrm{O}_{2} \mathrm{Br}_{5} & 40.58\end{array}$

The above result agrees with the tetrabromide of stigmasterine acetate. 
Owing to the scarcity of the material, the free stigmasterine could not be obtained.

(4) Anderson's $\gamma$-sitosterine ${ }^{(4)}$.

The bromides in the mother liquor of the above tetrabromide were combined, dissolved in ether and fractionally precipitated with methyl alcohol. The main fraction thus obtained was an amorphous powder, melting at $130^{\circ} \mathrm{C}$. It was debrominated by boiling with zinc dust and acetic acid, and an acetyl derivative (m. p. $143^{\circ} \mathrm{C},[\alpha]_{\mathrm{D}}^{20}=-44.70^{\circ}$ ) was prepared. By saponifying the latter, a free sterol (m. p. $148^{\circ} \mathrm{C},[\alpha]_{\mathrm{D}}^{21}=-42.3^{\circ}$ ) was isolated.

Analysis of the free sterol:

$\begin{array}{ccccc}\text { Substance (mg) } & \mathrm{CO}_{2}(\mathrm{mg}) & \mathrm{H}_{2} \mathrm{O}(\mathrm{mg}) & \mathrm{C}(\%) & \mathrm{H}(\%) \\ 4.013 & 12.270 & 3.950 & 83.39 & 12.30 \\ & \text { Calculated for } & \mathrm{C}_{99} \mathrm{H}_{50} \mathrm{O} & 83.96 & 12.24\end{array}$

The analysis shows that it agrees with Anderson' $\gamma$-sitosterol.

(5) A new sitosterol.

The sterol acetates descrbied above were combined and saponified. About $80 \mathrm{~g}$ free sterol thus obtained, was dissolved in hexane and fractionally precipitated by gradual cooling as follows:

\begin{tabular}{l|c|c|c|c}
\hline & Temperature $\left({ }^{\circ} \mathrm{C}\right)$ & Yield $(\mathrm{g})$ & $\mathrm{m} . \mathrm{p} .\left(^{\circ} \mathrm{C}\right)$ & $\mathrm{D}$ \\
\hline I & 21 & 19.5 & 135 & $-29.34^{\circ}\left(21^{\circ} \mathrm{C}\right)$ \\
II & 1 & 16.5 & 134 & $-23.93^{\circ}\left(20^{\circ} \mathrm{C}\right)$ \\
III & -12 & 20.0 & 132 & $-18.46^{\circ}\left(18^{\circ} \mathrm{C}\right)$ \\
IV (residue) & & 22.0 & 148 & - \\
\hline
\end{tabular}

The author could not separate from the above fraction I, II, III any substance that had constant melting point and rotation. The last fraction (IV) was recrystallized from absolute alcohol ten times, from acetone twice and further from methyl alcohol fifteen' times and a new sitosterol (m. p. $\left.156^{\circ} \mathrm{C},[\alpha]_{\mathrm{D}}^{2 \mathrm{~s}}=-14.485^{\circ}\right)$ was isolated; yield, $2.1 \mathrm{~g}$. It was more readily soluble in organic solvents than other sterines.

Analysis of the new sitosterol:

\begin{tabular}{cccccc} 
& Substace (mg) & $\mathrm{Co}_{2}(\mathrm{mg})$ & $\mathrm{H}_{2} \mathrm{O}(\mathrm{mg})$ & $\mathrm{C}(\%)$ & $\mathrm{H}(\%)$ \\
$\mathrm{I}$ & 3.269 & 10.040 & 3.495 & 83.76 & 11.96 \\
II & 4.144 & 12.690 & 4.510 & 83.52 & 12.18 \\
& & \multicolumn{2}{c}{ Calculated for $\mathrm{C}_{27} \mathrm{H}_{46} \mathrm{O}$} & 83.85 & 12.01
\end{tabular}

The acetate of the new sitosterol was prepared by boiling the free sterol with acetic anhydride for 40 minutes in the usual way; m. p. $111^{\circ} \mathrm{C},[\alpha]_{\mathrm{D}}^{23}=$ $-9.87^{\circ}$.

Analysis of the acetate: 


\begin{tabular}{cccccc} 
& Sulstance (mg) & $\mathrm{CO}_{2}(\mathrm{mg})$ & $\mathrm{H}_{2} \mathrm{O}(\mathrm{mg})$ & $\mathrm{C}(\%)$ & $\mathrm{H}(\%)$ \\
I & 3.472 & 10.370 & 3.608 & 81.46 & 11.63 \\
II & 3.849 & 11.467 & 3.949 & 81.25 & 11.48 \\
& \multicolumn{2}{r}{ Calculated for $\mathrm{C}_{29} \mathrm{H}_{48} \mathrm{O}_{2}$} & & 81.21 & 11.30
\end{tabular}

The propionate was obtained by boiling the free sterol with propionic anhydride for 1.5 hours in the usual way; m. p. $106^{\circ} \mathrm{C},[\mathrm{a}]_{\mathrm{D}}^{33}=-6.78^{\circ}$

Analysis of the propionate:

\begin{tabular}{cccccc} 
& Substance (mg) & $\mathrm{CO}_{2}(\mathrm{mg})$ & $\mathrm{H}_{2} \mathrm{O}(\mathrm{mg})$ & $\mathrm{C}(\%)$ & $\mathrm{H}(\%)$ \\
I & 3.003 & 8.992 & 3.177 & 81.66 & 11.84 \\
II & 3.610 & 10.800 & 3.750 & 81.59 & 11.62 \\
& \multicolumn{2}{r}{ Calculated for $\mathrm{C}_{30} \mathrm{H}_{50} \mathrm{O}_{2}$} & & 81.74 & 11.60
\end{tabular}

The benzoate was obtained by adding benzoylchloride to the sterol dissolved in pyridine at $2^{\circ} \mathrm{C} ; \mathrm{m}$. p. $129^{\circ} \mathrm{C},[\alpha]_{\mathrm{D}}^{20}=+14.48^{\circ}$

Analysis of the benzoate:

\begin{tabular}{cccccc} 
& Substance (mg) & $\mathrm{CO}_{2}(\mathrm{mg})$ & $\mathrm{H}_{2} \mathrm{O}(\mathrm{mg})$ & $\mathrm{C}(\%)$ & $\mathrm{H}(\%)$ \\
$\mathrm{I}$ & 2.981 & 9.071 & 2.885 & 82.49 & 10.83 \\
$\mathrm{II}$ & 3.660 & 11.178 & 3.577 & 83.29 & 10.93 \\
& \multicolumn{2}{r}{ Calculated for $\mathrm{C}_{3.4} \mathrm{H}_{5.4} \mathrm{O}_{2}$} & & 83.21 & 10.28
\end{tabular}

The ac̀etate mentioned above was brominated by the Windaus-Hauth method, but when a small amount of bromine was added, the solution became brownish green, liberating $\mathrm{HBr}$ and required $50 \%$ more bromine than the calculated quantity. When bromine was added at $-13^{\circ} \mathrm{C}$, the green colour never appeared, only turning brown. The percentage of bromine was found to be 31.89 and $32.27 \%$. A portion of the sterol was reduced with hydrogen using platinum-black as the catalyst, but the reduction proceeded very slowly, so that the Liebermann-Buchard reaction never disappeared. The molecular formula of the sterol calculated from its analytical results corresponds to $\mathrm{C}_{2 i} \mathrm{H}_{46} \mathrm{O}$.

From the above observation it was believed to be an isomer of Burian's sitosterol. The so-called Anderson's $\alpha$-sitosterol was still a mixture of various sterols, as is shown in the following table:

\begin{tabular}{l|c|c|c|c}
\hline \multirow{2}{*}{} & \multicolumn{2}{|c|}{ Free sterol } & \multicolumn{2}{c}{ Acetate } \\
\cline { 2 - 5 } & m. p. $\left({ }^{\circ} \mathrm{C}\right)$ & Rotation & m. p. $\left({ }^{\circ} \mathrm{C}\right)$ & Rotation \\
\hline a-Sitosterol & $138 \sim 140$ & $-23.41^{\circ}$ & $115 \sim 116$ & $-23.91^{\circ}$ \\
Author's new sterol & 156 & $-14.485^{\circ}$ & 111 & $-9.87^{\circ}$ \\
\hline
\end{tabular}

(B) The brown syrup.

The brown syrup was subjected to steam distillation and a little oil having a characteristic odour was obtained, but the amount was so small that it could not be examined further. From the residue, when further distilled 
at high vacuum a hydrocarbon mixed with a little higher alcohol was obtained.

(VIII) Wax.

When rice-embryo was boiled with strong alcohol or benzene, then filtered while hot and the filtrate was left to stand for several hours, the waxy substance separated out as a greyish white flocky precipitate, or when the crude embryo oil was treated with ether, the waxy substance remained as an insoluble residue. These were combined and extracted with hot benzene in Soxhlet apparatus and the extract was precipitated with ether. By repeating this operation five times needle-shaped crystals melting at $82^{\circ} \mathrm{C}$ were obtained; yiẹld, $3.2 \mathrm{~g}$.

The analysis gave the following results:

\begin{tabular}{|c|c|c|c|c|c|}
\hline & Substance (mg) & $\mathrm{CO}_{2}$ (ng) & $\mathrm{H}_{2} \mathrm{O}$ (ng) & $\mathrm{C}(\%)$ & II $(\%)$ \\
\hline l & 4.000 & 12.055 & 4.954 & 82.19 & 13.86 \\
\hline & 3.840 & 11.642 & 4.858 & $82.17^{\circ}$ & 14.07 \\
\hline & \multicolumn{3}{|c|}{ Calculated for $\mathrm{C}_{65} \mathrm{H}_{112} \mathrm{O}_{2}$} & 82,06 & 14.03 \\
\hline
\end{tabular}

The analysis shows that it was melissyl cerotate.

For further identification, this substance was saponified by boilling with $5 \%$ potassium alcoholate for 4 hours. After cooling, the mixture was treated with alcoholic $\mathrm{CaCl}_{2}$. The calcium soap thus formed was filtered off, and the filtrate was completely dried and extracted with benzene. The benzene solution was evaporated and the residue was recrystallized from absolute alcohol. In this way hair-like needles melting at $85^{\circ} \mathrm{C}$ were obtained.

Analysis of the sample:

$\begin{array}{ccccc}\text { Substance }(\mathrm{mg}) & \mathrm{CO}_{2}(\mathrm{mg}) & -\mathrm{H}_{2} \mathrm{O}(\mathrm{mg}) & \mathrm{C}(\%) & \mathrm{H}(\%) \\ 4.100 & 12.400 & 5.230 & 82.48 & 14.27 \\ & \text { Calculated for } \mathrm{C}_{30} \mathrm{H}_{62} \mathrm{O} & 82.08 & 14.28\end{array}$

The result agrees with melissyl alcohol.

The Ca-soap obtained as above, was decomposed with dilute hydrochloric acid $(1: 1)$ and cerotic acid was isolated as insoluble crystalline powder. After recrystallization from absolute alcohol, it melted at $78^{\circ} \mathrm{C}$ and had the mean molecular weight 394 . Mixed with a pure specimen of cerotic acid, no depression of melting point was observed.

(XI) Cerebroside.

When rice-embryo, previously extracted with benzol, was boiled with 85 $\sim 90 \%$ methyl alcohol and the methyl alcoholic solution was evaporated in vacuum to a syrupy consistency and left standing for several days, a solid substance separated out. It was collected by suction and dissolved in ether. The etherial solution thus obtained was, after washing with water, treated with acetone, whereby a precipitate was formed which gave ninhydrine and 
Molisch's rèactions. This precipirate was dissolved in ether and precipitated by adding absolute alcohol. By repeating this operation four times, a crystalline substance was obtained which gave no more the above reactions. When dried in vacuum desiccator it became brownish black and was no more soluble in ether. The mother liquor of the above crystals was shaken with water and the separated ether layer was dehydrated, evaporated to a small volume and treated with acetone, whereby a precipitate was formed, which when recrystallized from absolute alcohol gave ninhydrine and Molish's reactions. It resembled the cerebroside, obtained by Trier from rice grain. Owing to the scarcity of the material, it was not further investigated. Details concerning this part will be published later.

In conclusion, the authors wish to express their sincere thanks to Prof. Dr. U. Suzuki for his advices and encouragement throughout this work and also to Mr. T. Iki and T. Tanaka for micro-analysis.

\section{Studies on the Fermentation products by Mould Fungi. Part X.}

Glaucic Acid formed by : Aspergillus glaucus.

(Aspergillus glaucus. IV.)

$$
\text { By }
$$

Yusuke Sumiki.

(Agricultural Chemical Laboratory, Tokyo Imperial University).

(Received May 23, 1933).

On the previous report of this series (part IV), the author described that a new crystal substance, m.pt. $238 \sim 9^{\circ}$, was obtained by the cultivation of Aspergillus glaucus under a certain condition. Since, the author cultivated Aspergillus glaucus several times under the same condition but could not obtain this crystal substance. Unexpectedly, the author obtained this substance by treating the mycelium of Aspergillus glaucus with ether on account of the isolation of chitin from the mycelium. This new crystal substance was named glaucic acid after Aspergillus glaucus.

Glaucic acid melts at $238 \sim 9^{\circ}$ and contains no nitrogen, methoxyl, ketomethylen and methylenoxide groups. The results of analyses of glaucic acid and its derivative show that the molecular formula of glaucic acid is $\mathrm{C}_{17} \mathrm{H}_{22} \mathrm{O}_{5}$. 